\title{
Numerical chromosomal aberrations in Hodgkin's disease detected by in situ hybridisation on routine paraffin sections
}

Department of Pathology, University of Leicester, Robert Kilpatrick Clinical Sciences Building, PO Box 65, Leicester Royal Infirmary, Leicester LE2 7LX, UK

Correspondence to: Dr Pringle.

Accepted for publication 8 April 1997

\begin{abstract}
Aims-To visualise directly numerical chromosomal aberrations and polyploidy in both Hodgkin and Reed Sternberg (HRS) cells and background cells from cases of Hodgkin's disease using in situ hybridisation.

Methods-Non-isotopic DNA in situ hybridisation was applied to interphase cell nuclei of Hodgkin's disease within routine paraffin embedded tissue sections. Two $\alpha$ satellite DNA probes, specific for chromosomes 3 and 12, were used to evaluate the feasibility of this approach. Double labelling with immunocytochemical detection of the CD30 antigen was used to identify HRS cells. Cytogenetic normal diploid and triploid placental tissue served as controls.

Results-The eight cases of Hodgkin's disease investigated displayed frequent polysomy, while the majority of background cells showed disomy signals.

Conclusions-Numerical chromosomal aberrations were detected in HRS cells from eight cases of Hodgkin's disease by in situ hybridisation. These data show that in Hodgkin's disease HRS cells frequently display polyploidy compared with background cells and are, therefore, probably the only neoplastic component in this disease. Correlations between polysomy and tumour type or grade could not be made from these data owing to the limited number of cases examined and to problems with interpreting data from truncated nuclei.

( Clin Pathol 1997;50:553-558)
\end{abstract}

Keywords: Hodgkin's disease; chromosome aberrations; polyploidy; in situ hybridisation

Many different tumours are characterised by specific chromosomal aberrations, which can be useful for defining those with a similar biological background. The detection of particular chromosomal aberrations can also be useful both for diagnosis and assessment of prognosis. ${ }^{1}$

Hodgkin's disease is characterised by a small number of putative malignant cells, the mononuclear Hodgkin and multinucleated Reed Sternberg (HRS) cells. These cells usually comprise less than $2 \%$ of the tumour mass, among a background of lymphocytes, plasma cells, histiocytes, neutrophils, eosinophils, and stromal cells. The lineage of HRS cells remains elusive and the histopathological designation of Hodgkin's disease is likely to encompass a number of distinct immunophenotypic and immunogenetic entities. Two key subtypes of the disease, nodular sclerosing and mixed cellularity, both characterised by expression of the $\mathrm{CD} 30$ and $\mathrm{CD} 15$ antigens, ${ }^{2}$ were considered in this study.

Cytogenetic studies of Hodgkin's disease have presented particular problems owing to: the rarity of HRS cells in cellular material from biopsied lymph nodes; HRS cells having low mitotic indices; and the typically complex karyotypes of these cells and difficulties with banding. ${ }^{3}$ Teerenhovi et al were the first to demonstrate successfully that clonal chromosomal abnormalities are carried by HRS cells expressing the CD15 and CD30 antigens. ${ }^{4}$ Other cytogenetic studies of Hodgkin's disease have reported cytogenetic changes typical of B cell lymphomas, ${ }^{5} \mathrm{~T}$ cell malignancies, ${ }^{6}$ and numerous other chromosomal abnormalities. ${ }^{78}$ Numerical abnormalities, both gain and loss of chromosome copy number, have been identified for virtually all chromosomes. Structural changes (for example, translocations and deletions) are also common, although no single abnormality predominates. One study that identified frequent loss or deletion of chromosome $4 \mathrm{q} 25-4 \mathrm{q} 27^{9}$ is noteworthy, as loss of this region has not been reported previously in other human malignancies. However, no clear correlations have been determined between the numerous chromosomal abnormalities and either clinicopathological features or prognosis. ${ }^{7}$ This might be explained by the fact that the metaphases analysed may not necessarily be derived from the malignant cells or might reflect distinct genetic entities.

Non-isotopic in situ hybridisation (NISH) is a powerful method for discriminating numerical chromosomal changes in interphase cell nuclei in solid tumours. ${ }^{10}$ The method can be used on tissue sections, allowing combined cytogenetic and histological analyses. ${ }^{11}{ }^{12}$ To resolve some of the problems associated with cytogenetic studies of Hodgkin's disease, we used NISH with chromosome specific repetitive DNA probes to interphase cell nuclei of nodular sclerosing and mixed cellularity Hodgkin's disease within routine paraffin wax embedded tissue sections. In situ hybridisation was also carried out after immunocytochemical detection of the CD30 antigen to identify HRS cells. Chromosome specific $\alpha$ satellite DNA 
Table 1 Tumour and patient features for eight cases of Hodgkins's disease

\begin{tabular}{llll}
\hline Case & Sex & $\begin{array}{l}\text { Age } \\
\text { (years) }\end{array}$ & $\begin{array}{l}\text { Histopathological } \\
\text { diagnosis }\end{array}$ \\
\hline 1 & Male & 18 & NS grade 1 \\
2 & Male & 27 & NS grade 1 \\
3 & Male & 16 & NS grade 1 \\
4 & Female & 32 & NS grade 2 \\
5 & Female & 5 & MC \\
6 & Female & 39 & NS grade 1 \\
7 & Male & 22 & NS grade 2 \\
8 & Female & 21 & NS grade 1 \\
\hline
\end{tabular}

MC, mixed cellularity; NS, nodular sclerosing.

probes from chromosomes 3 and 12 were used to illustrate numerical chromosomal aberrations.

\section{Methods}

HISTOLOGICAL MATERIAL

Eight histologically unequivocal cases of Hodgkin's disease were selected from the pathology archives of Leicester University and the Leicester Royal Infirmary (table 1). Formalin fixed paraffin wax embedded biopsy material, taken for histological evaluation, was studied in each case. None of the patients had undergone any therapy at the time of biopsy. Normal diploid and cytogenetic triploid placental tissues served as controls.

DNA PROBES AND PROBE LABELLING

Pericentromeric $\alpha$ satellite DNA probes specific for chromosomes 3 and 12 (D) $31^{13}$ and D $12 Z^{14}$ ) were selected for study. Recombinant DNA clones were obtained from the American Type Culture Collection (ATCC, Rockville, Maryland, USA). For in situ hybridisation $2 \mu \mathrm{g}$ of each plasmid DNA was labelled with digoxigenin-11-dUTP (Boehringer Mannheim, Germany) by random priming ${ }^{15}$ modified for non-isotopic labelling. ${ }^{11}$

\section{CHROMOSOME IN SITU HYBRIDISATION}

The DNA in situ hybridisation procedure ${ }^{11}$ was performed as follows: $5 \mu \mathrm{m}$ paraffin sections were mounted on silane coated slides, dried, heated, and dewaxed. The slides were transferred to $50 \mathrm{mM}$ Tris $\mathrm{HCl} \mathrm{pH} 7.65$ and digested with proteinase $\mathrm{K}$ (Boehringer Manheim) solutions in Tris $\mathrm{HCl}$ at concentrations ranging from 25 to $50 \mu \mathrm{g} / \mathrm{ml}$ for one hour at $37^{\circ} \mathrm{C}$ in a humidity chamber. This was followed by treatment with $0.4 \%$ paraformaldehyde, $0.1 \mathrm{M}$ phosphate buffered saline at $4^{\circ} \mathrm{C}$ (using precooled solutions) and ultra pure water $(\times 2)$ before prehybridisation. The optimum concentration of proteinase $\mathrm{K}$ was determined for each case to obtain an optimal balance between morphological preservation and DNA target accessibility.

Prehybridisations were carried out for one hour at $42^{\circ} \mathrm{C}$ with an overlay of hybridisation buffer $(50 \%$ formamide, $2 \times$ saline sodium citrate (SSC) $10 \%$ dextran sulphate, $1 \mathrm{mM}$ Tris pH 7.5, $100 \mu \mathrm{M}$ EDTA pH 8.0). Fresh hybridisation buffer containing $500 \mathrm{ng} / \mathrm{ml}$ of digoxigenin labelled probe and $500 \mu \mathrm{g} / \mathrm{ml}$ sonicated salmon sperm DNA was then added. This buffer was located over the section using a coverslip. Chromosomal DNA and probe
DNA were denatured by heating for 10 minutes at $100^{\circ} \mathrm{C}$ and hybridisations were carried out overnight at $42^{\circ} \mathrm{C}$ in a humidified chamber. Post-hybridisation washes at $42^{\circ} \mathrm{C}$ comprised: $3 \times 10$ minutes in $50 \%$ formamide, $1 \times$ SSC, followed by 30 minutes in $0.1 \times$ SSC, $2 \mathrm{MgCl}_{2}, 0.1 \%$ Triton X100. In situ signals were visualised by incubation for 30 minutes in a 1/4000 dilution of an anti-digoxigenin monoclonal antibody (Boehringer Mannheim) in blocking solution (3\% bovine serum albumin, $1 \times$ Tris buffered saline (TBS), $0.1 \%$ Triton $\mathrm{X} 100$ ) followed by a similar incubation in a $1 / 400$ dilution of biotinylated rabbit antimouse antibody (Dako, UK) and a streptavidinbiotinylated peroxidase complex (SABC-Px; Dako) method using diaminobenzidine (DAB) with nickel (diammonium nickel sulphate 6 hydrate) enhancement to give dark brown spots at the location of specific in situ hybrids. ${ }^{11}$ Sections were counterstained with $0.1 \% \mathrm{nu}-$ clear fast red, dehydrated, immersed in xylene, and mounted in DPX.

\section{IN SITU HYBRIDISATION WITH CD30}

IMMUNOCYTOCHEMISTRY

Paraffin sections ( $5 \mu \mathrm{m}$ thick) were mounted on silane coated slides, dried, heated, dewaxed, and immersed in ultra pure water. Antigen retrieval was achieved by heating sections submerged in $10 \mathrm{mM}$ citric acid $(\mathrm{pH} \mathrm{6.0)}$ in a domestic microwave oven $(850 \mathrm{~W})$ on full power for 60 minutes. Slides were allowed to cool to room temperature in the citrate buffer and then rinsed for $2 \times 5$ minutes in TBS. Sections were incubated with an overlay of a $1 / 5$ dilution of normal rabbit serum (Dako) in blocking solution for 10 minutes, followed by incubation in a $1 / 10$ dilution in blocking solution of anti-CD30 antibody (Ber H2; Dako) overnight at $4^{\circ} \mathrm{C}$. Slides were treated sequentially with TBS and biotinylated rabbit antimouse antibody (1/400 dilution in blocking solution; Dako) for 30 minutes; TBS and SABC-AP for 30 minutes; TBS, ultra pure water, $1 \times$ veronal acetate buffer $(\mathrm{VAB} ; 30 \mathrm{mM}$ sodium acetate trihydrate, $30 \mathrm{mM}$ sodium barbitone, $100 \mathrm{mM}$ sodium chloride, $50 \mathrm{mM}$ magnesium chloride hexahydrate, $\mathrm{pH} 9.2$ ), and fast red developer (50 mg fast red TR salt (F 2768, Sigma); $50 \mathrm{mg}$ napthol ASBI phosphate (N 2250, Sigma) predissolved in 1 $\mathrm{ml}$ dimethyl formamide and $24 \mathrm{mg}$ levamisole (L 9756, Sigma) in $100 \mathrm{ml} \mathrm{VAB} \mathrm{pH} \mathrm{9.2)} \mathrm{for}$ one hour and then immersed in ultra pure water. Sections were then hybridised with digoxigenin labelled probes as described above, starting at the prehybridisation step, slides were then rinsed in tap water, air dried, immersed in xylene, and mounted in DPX.

CD30 only controls were stained in Mayer's haematoxylin for one minute, cleared in tap water, and mounted in aqueous mount.

\section{EVALUATION OF NISH RESULTS}

Sections were evaluated using previously defined criteria as follows. Haematoxylin and eosin stained sections from each case were checked to ensure that they were representative of the lesion and for preservation of its general 
Table 2 Combined data for chromosome specific signals in eight cases of Hodgkin's disease, diploid controls, and triploid controls

\begin{tabular}{|c|c|c|c|c|c|}
\hline \multirow[b]{2}{*}{ Case } & \multirow[b]{2}{*}{ Probe } & \multicolumn{3}{|c|}{ Percentage of cells with number of spots } & \multirow[b]{2}{*}{ Ploidy } \\
\hline & & $0-2$ & $3-4$ & $5-6$ & \\
\hline \multirow[t]{2}{*}{1} & 3 & 46 & 51.5 & 2.5 & Trisomy/tetrasomy \\
\hline & 12 & 66.5 & 31 & 2.5 & Trisomy/tetrasomy \\
\hline \multirow[t]{2}{*}{2} & 3 & 27 & 57 & 16 & Polysomy \\
\hline & 12 & 25 & 55 & 20 & Polysomy \\
\hline \multirow[t]{2}{*}{3} & 3 & 25 & 60 & 15 & Polysomy \\
\hline & 12 & 27 & 62 & 11 & Polysomy \\
\hline \multirow[t]{2}{*}{4} & 3 & 32 & 61 & 7 & Polysomy \\
\hline & 12 & 31 & 62 & 7 & Polysomy \\
\hline \multirow{2}{*}{5} & 3 & 61.5 & 34 & 4.5 & Trisomy/tetrasomy \\
\hline & 12 & 75 & 25 & 0 & Trisomy/tetrasomy \\
\hline \multirow[t]{2}{*}{6} & 3 & 29 & 59.5 & 11.5 & Polysomy \\
\hline & 12 & 32 & 62.5 & 5.5 & Polysomy \\
\hline \multirow[t]{2}{*}{7} & 3 & 67.5 & 31.5 & 1 & Trisomy/tetrasomy \\
\hline & 12 & 62 & 36.5 & 1.5 & Trisomy/tetrasomy \\
\hline \multirow[t]{2}{*}{8} & 3 & 60 & 35.5 & 4.5 & Trisomy/tetrasomy \\
\hline & 12 & 56.5 & 40 & 3.5 & Trisomy/tetrasomy \\
\hline \multirow[t]{2}{*}{ Diploid control } & 3 & 98.0 & 2.0 & 0 & Disomy \\
\hline & 12 & 97.5 & 2.5 & 0 & Disomy \\
\hline \multirow{2}{*}{ Triploid control } & 3 & 74.5 & 25.5 & 0 & Trisomy \\
\hline & 12 & 67.0 & 32.0 & 1 & Trisomy \\
\hline
\end{tabular}

Hodgkin's disease cases 1 to 8 , counts for HRS cells only are given.

architecture. Optimal slides for evaluation of in situ signals were then selected. These were ones with well preserved HRS cells in combination with clear, distinct in situ spots. One hundred HRS cell nuclei and 100 background cells from each case of Hodgkin's disease, selected from random fields, were scored for the number of in situ spots (0-6) by two observers (JHP, JAS). One hundred large stromal cells from the cytogenetic controls were counted by one observer (AG) as these cells were of a similar size to the HRS cells. These data were pooled into three categories: $0-2$ spots, 3-4 spots, and 5-6 or more spots.

\section{Results}

Table 1 lists the clinical diagnoses of the eight Hodgkin's disease cases studied. Seven of the eight cases were of the nodular sclerosing type grade 1 or 2 , and one case was of mixed cellularity Hodgkin's disease. In each case, diagnostic biopsy material was studied and none of the cases had undergone any therapy at the time of biopsy. The reliability of the in situ method was tested by hybridisation to interphase nuclei of normal diploid and cytogenetic triploid control tissues prepared from placentas (figs 1 and $2 F$, and table 2). In each case, it was necessary to focus through the nucleus to detect all signals clearly. The diploid control showed 0-2 spots in $97.5-98 \%$ of cells analysed with both chromosome probes and the triploid control showed $0-3$ in situ signals in $93.0 \%$ and $91.0 \%$ of cells analysed with the chromosome 3 and 12 probes, respectively (table 2 and fig 2B). Both the diploid and triploid controls showed consistent data. These controls illustrate the reduction in counts owing to large cells with truncated nuclei. The observer variation was not significant for controls or Hodgkin's disease cases. The quality of the nuclear morphology in the Hodgkin's and control tissues was reduced by proteinase $\mathrm{K}$ pretreatment, which is necessary for the in situ hybridisation technique. Therefore, nuclear fast red was used on the controls to identify
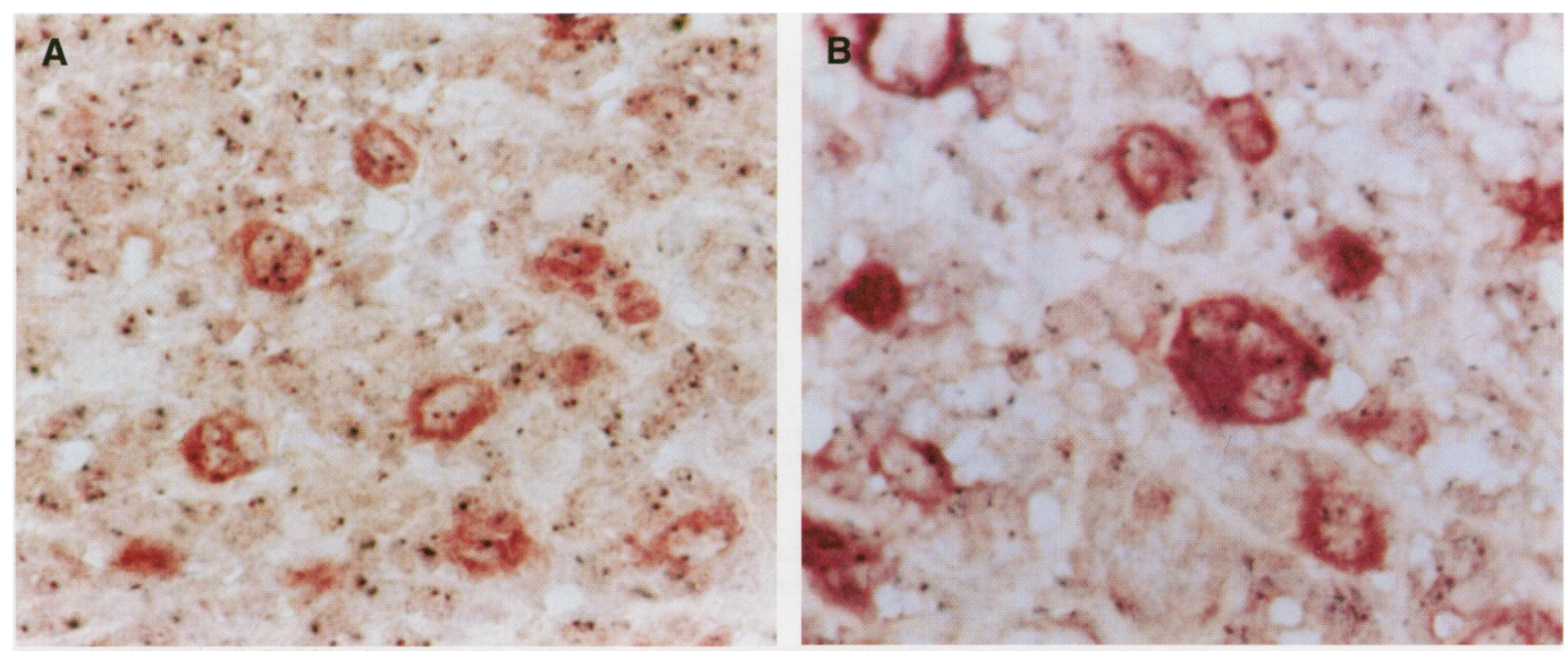

Figure 1 Non-isotopic DNA in situ hybridisation (NISH) for chromosomes 3 and 12 for two cases of Hodgkin's disease, normal diploid controls, and triploid controls. (A) CD3O immunocytochemistry and NISH with the D12Z3 probe within a $5 \mu \mathrm{m}$ section of Hodgkin's disease case 1. HRS cells can be distinguished showing cytoplasmic staining for CD3O and nuclei with three or more spots indicating polysomy. (B) CD30 immunocytochemistry and NISH with the D12Z3 probe within a $5 \mu \mathrm{m}$ section of Hodgkin's disease case 7. HRS nuclei can be distinguished showing polysomy. (C) Diploid placental control showing NISH results for chromosome 12. The majority of cells show two nuclear spots. (D) Triploid control showing NISH results on placental tissue for chromosome 3. The majority of cells show three
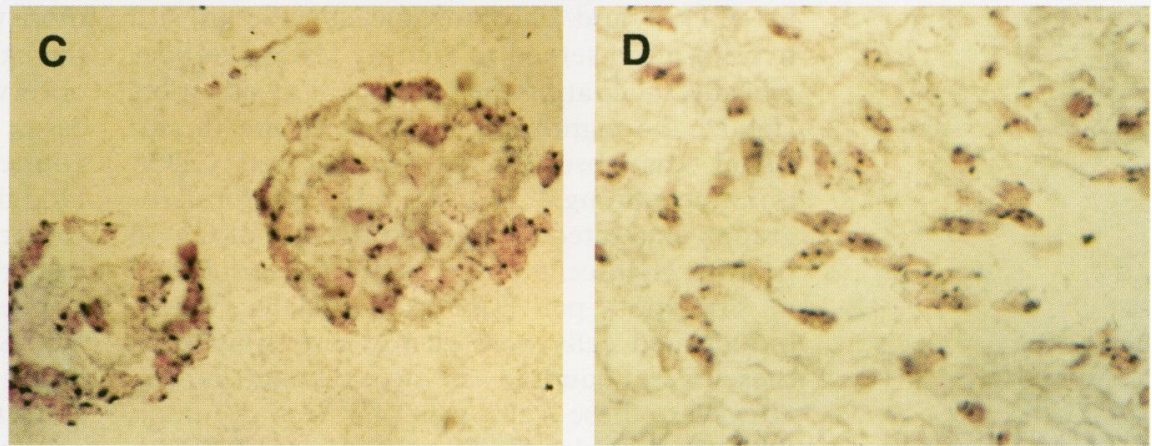
nuclear spots. 


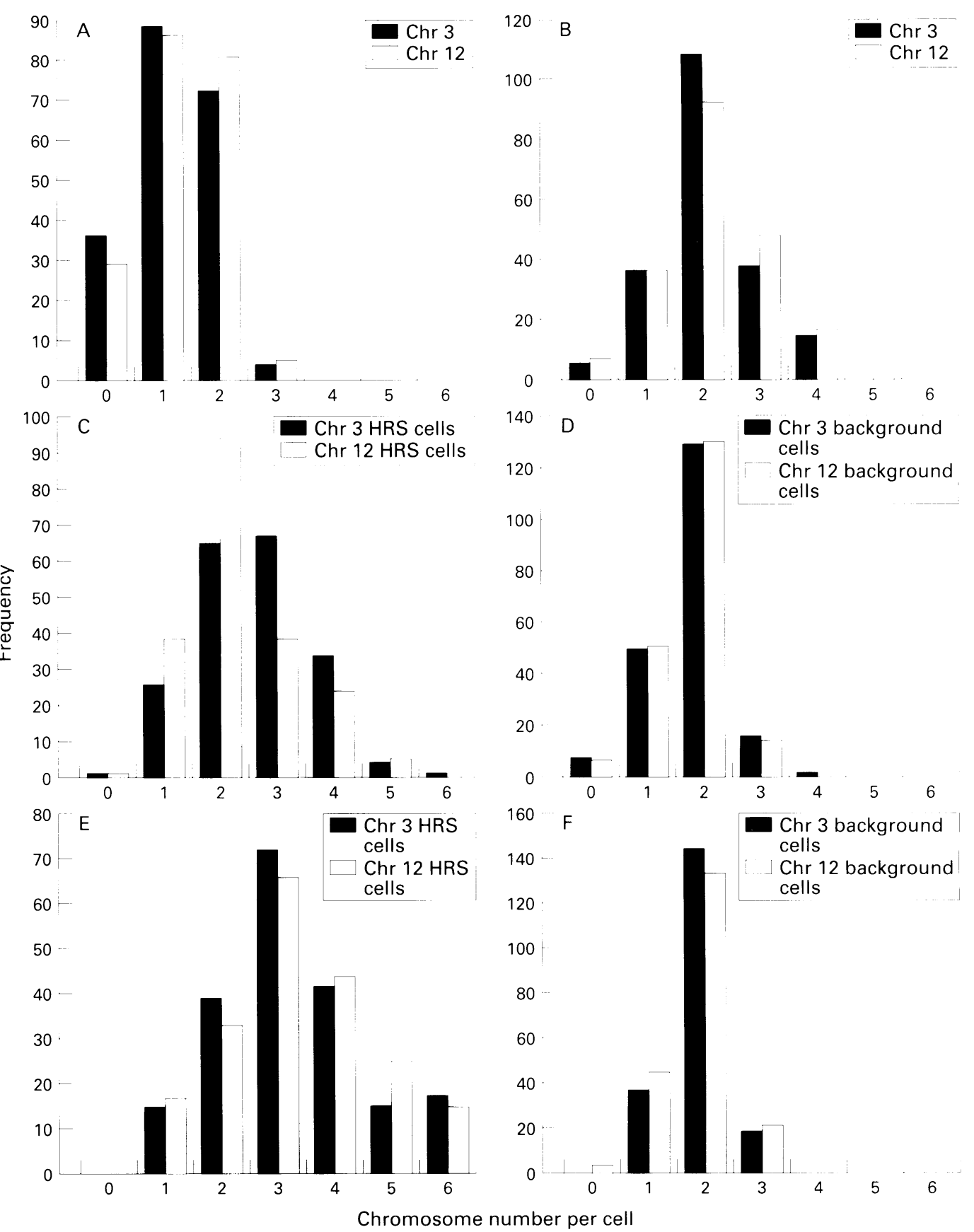

Figure 2 DNA probe frequency distributions showing the number of hybridisation spots per nucleus for Hodgkin's disease cases and controls after NISH using the two probes and $5 \mu \mathrm{m}$ tissue sections. (A) Diploid control showing diploid NISH profile; (B) cytogenetic triploid control showing triploid profile; (C) case 1 Hodgkin and Reed Steinberg (HRS) cell profile; (D) case 1 background cell profile; (E) case 2 HRS cell profile; (F) case 2 background cell profile.

individual nuclei and no counterstaining was necessary where CD30 immunostaining was used to identify HRS cells.

The combination of immunocytochemistry for CD30 and chromosome specific in situ hybridisation served to identify HRS cells specifically, facilitating the analysis of in situ spots (fig 1). No significant masking of the in situ signal was observed by the fast red CD30 immunostaining. The in situ photomicrographs illustrated clearly that the size of CD30 positive HRS cells varied as did the number of in situ spots per HRS cell nucleus. Where binucleated cells were clearly distinguishable, these were counted as two distinct nuclei. However, these cells were far less common than mononuclear HRS cells. Figure 2 shows DNA probe frequency distributions for Hodg- kin's disease cases 1 and 2 (both HRS and background nuclei) and the diploid and triploid controls. These data show that the number of spots per HRS cell nucleus varied more widely than for the background cells from the same case. The pooled in situ data (both observers) from the eight Hodgkin's disease cases, normal diploid controls, and triploid controls are summarised in table 2. For all Hodgkin's cases, only the HRS cell counts are presented in table 2 as counts for the background cell populations predominantly showed disomy for both probes (0-2 spots in $>90 \%$ of nuclei counted) (figs $2 \mathrm{D}$ and $2 \mathrm{~F}$ ). A larger proportion of these cells showed two spots than for the diploid control because these cells were smaller and less prone to nuclear truncation effects. Rare background cells with 
three spots $(<10 \%)$ are likely to reflect the close proximity of two small nuclei rather than genuine trisomy.

Four of the eight Hodgkin's disease cases (2, 3 , 4, and 6) showed polysomy with more than $65 \%$ of HRS cells having three or more in situ signals with both chromosome probes (table 2). The remaining Hodgkin's disease cases appeared to show trisomy/tetrasomy for both chromosome probes as 5-6 in situ signals were rare $(<5 \%)$. Of these cases, one showed more frequent trisomy/tetrasomy for the D3Z1 probe than for the D12Z3 probe. These results show that clear numerical chromosome data can be obtained from the HRS cells and background cells.

\section{Discussion}

NISH with chromosomes 3 and 12 specific $\alpha$ satellite DNA probes to paraffin archival tissue sections allowed us to screen eight cases of Hodgkin's disease for the presence of numerical aberrations of the selected chromosomes. Chromosomes 3 and 12 were selected as numerical aberrations of these chromosomes had been observed previously in metaphase analyses of Hodgkin's disease. ${ }^{16}$ In combination with immunocytochemistry to mark the CD30 antigen, this approach delineated specific HRS cells that showed clear numerical chromosomal aberrations, frequently polysomy, while the background cell populations were mostly diploid for the two chromosomes studied. For the in situ studies carried out without CD30 detection the tissue architecture was retained sufficiently to enable histological examination and the identification of HRS cells. Hence, it was possible to distinguish directly between HRS and background cells using both approaches. The analysis of interphase nuclei in tissue sections, therefore, offers certain advantages over other techniques that use isolated cells or tissue extracts. Moreover, the background cells give useful information with repect to hybridisation efficiency and patient genetics.

Despite sectioning, which yields sliced nuclei, specific aberrations were detected for HRS cells from all eight Hodgkin's disease cases studied, with all cases showing polysomy, although the frequency of polysomy varied. Three cases showed approximately $30 \%$ of HRS cells having trisomy/tetrasomy of both chromosome 3 and 12 . One case appeared to show more frequent trisomy/tetrasomy for the $\mathrm{D} 3 \mathrm{Z} 1$ probe than for the $\mathrm{D} 12 \mathrm{Z} 3$ probe and four cases showed more than $65 \%$ of HRS cells with three signals or more for both chromosome probes. It is noteworthy that no significant under-representation of either chromosome 3 or 12 was detected in any of the eight Hodgkin's disease cases studied. These data suggest that deletion of these two chromosomes may not be common in this disease.

It is difficult to distinguish accurately between trisomy, tetrasomy, and higher order polysomy, as not all nuclei in the plane of the section will retain their full chromosome complement. For this reason, these in situ data are likely to underestimate the true frequency of chromosomal aberrations. ${ }^{17}$ Moreover, the number of signals detected per nucleus is likely to become more variable as the chromosome copy number increases. Our data for the two cytogenetic controls appear to support this suggestion. For the diploid control, $98.0 \%$ of nuclei counted showed $0-2$ in situ signals (disomy), whereas for the cytogenetic triploid control fewer of the nuclei counted $(93.0 \%$ and $91.0 \%$ for the chromosome 3 and 12 probes, respectively) showed $0-3$ distinct in situ spots (table 2). These data suggest that the frequency of higher polysomy (trisomy or greater) is increasingly underestimated by this type of analysis.

The problem of chromosome retention on sectioning and, therefore, underestimation of actual chromosome number may be further compounded by the larger size of HRS cells compared with the background cells. The HRS cell chromosome number may vary also because of binucleated and multinucleated variants. In an attempt to address this problem, when binucleated HRS cells were clearly distinguishable, they were counted as two distinct nulcei. However, these were far less common than mononuclear variants. Despite these shortcomings, four of the eight Hodgkin's disease cases studied $(2,3,4$, and 6$)$ showed clearly a high frequency of polysomy $(>65 \%$ of HRS nuclei having three or more signals). The other four cases $(1,5,7$, and 8$)$ showed a lower but significant frequency of polysomy and, therefore, are more likely to have trisomy or tetrasomy. These data support previous studies where metaphase analyses of Hodgkin's disease revealed frequent trisomy and tetrasomy of both chromosomes 3 and $12 .{ }^{16}$ However, the variation in the number of spots detected within HRS cells for all eight cases might suggest that both inter- and intratumoral heterogeneity are common. As mentioned previously, the effects of nuclear truncation on sectioning are significant. Therefore, all the data should only be interpreted as providing global information about local differences in ploidy within a tumour. ${ }^{18}$

Weber-Matthiesen et $a l^{19}$ used simultaneous fluorescence immunophenotyping and interphase cytogenetics to study fresh cell preparations in 30 cases of Hodgkin's disease. These studies showed that HRS cells contained complex chromosome aberrations with hyperploidy predominating. Our findings from routine formalin fixed paraffin embedded diagnostic material for eight cases of Hodgkin's disease support these conclusions. Moreover, our method is applicable to a much wider range of stored tissue samples. One study, using interphase cytogenetics on fresh tissue samples, demonstrated that HRS cells obtained from different tissue samples from the same patient have a similar unique abnormal chromosomal pattern, leading the authors to suggest that HRS cells are clonal. ${ }^{20}$ However, we believe that it is difficult to establish by cytogenetic methods that these DNA changes are clonal. Indeed, we would argue that the intratumoural heterogeneity in chromosome copy number 
observed by us and previous studies ${ }^{19}{ }^{20}$ would suggest that HRS cells are not always clonal in origin.

The effective demonstration of clonality in Hodgkin's disease using immunoglobulin or $\mathrm{T}$ cell antigen receptor gene rearrangements has been limited to cases with large numbers of HRS cells where the clonal band can be assigned to these cells ${ }^{21}$ or analysis of microdissected single HRS cell DNA by the polymerase chain reaction. ${ }^{22}$ More convincing evidence that HRS cells are clonal populations has come from the analysis of Epstein-Barr virus infection of HRS cells and the demonstration that the viral genome is of clonal origin by Southern blotting. ${ }^{23}$ However, despite numerous studies of clonality in Hodgkin's disease there still remains a significant number of cases that appear to be polyclonal in origin. ${ }^{24}$ This leads to the possiblity that Hodgkin's disease starts as a polyclonal proliferation of HRS cells and subsequently develops into a monoclonal population as the disease progresses. ${ }^{25}$

In conclusion, we have demonstrated the utility of chromosome specific DNA in situ hybridisation for detecting numerical chromosomal aberrations in routine paraffin embedded tissue of Hodgkin's disease. These data show that in Hodgkin's disease HRS cells possess frequent polysomy compared to background cells and are, therefore, probably the only neoplastic component in the disease. No correlations between polysomy and either tumour type or grade could be made from these data, owing to both the limited number of cases examined and problems with interpreting data from truncated nuclei. If polysomy is a common feature of all cases of Hodgkin's disease, this information would have little prognostic significance, although it would indicate genomic instability of the HRS cells.

We thank Dr P McKeever (department of pathology, University of Leicester) for providing material for the cytogentic diploid and triploid controls.

1 Boehm T, Rabbitts TH. A chromosomal basis of lymphoid malignancy in man. Eur f Biochem 1989;185:1-17.

2 Drexler HG. Recent results on the biology of Hodgkin and Reed-Sternberg cells. I. Biopsy material. Leuk Lymph 1992; 8:283-313.

3 Rowley JD. Chromosomes in Hodgkin's disease. Cancer Treat Rep 1982;66:639-43.

4 Teerenhovi L, Lindholm C, Pakkala A, Franssila K, Stein H, Knutilla S. Unique display of a pathologic karyotype in
Hodgkin's disease by Reed-Sternberg cells. Cancer Genet Cytogenet 1988;34:305-11.

5 Cabanillas F, Pathak S, Trujillo J, Grant G, Cork A, Hagemeister FB, et al. Cytogenetic features of Hodgkin's disease suggest a possible origin from a lymphocyte. Blood 1988;71:1615.

6 Tilly $\mathrm{H}$, Bastard C, Delastre $T$, Duval C, Bizet $M$, Lenormand $\mathrm{B}$, et al. Cytogentic studies in untreated HodgLenormand B, et al. Cytogentic studies
kin's disease. Blood 1991;77:1298-304.

7 Ladanyi M, Parsa NZ, Offit K, Wachtel MS, Filippa DA, Jhanwar SC. Clonal cytogenetic abnormalities in Hodg kin's disease. Genes Chromosom Cancer 1991;3:294-9.

8 Ankathil R, Vijayakumar T, Pillai GR, Nair MK. Chromosomes in Hodgkin's disease - analysis of involved lymph nodes. Neoplasma 1992;39:245-8.

9 Dohner H, Bloomfield CD, Frizzera G, Frestedt J, Arthur JC. Recurring chromosome abnormalities in Hodgkin's disease. Genes Chromosom Cancer 1992;5:392-8.

10 Cremer T, Tesin D, Hopman AHN, Manuelidis L. Rapid interphase and metaphase assessment of specific chromosomal changes in neuroectodermal tumour cells by in situ hybridisation with chemically modified DNA probes. Exp Cell Res 1988;176:199-220.

11 Pringle JH, Homer CE, Warford A, Kendall CH, Lauder I. In situ hybridisation: alkaline phosphatase visualisation of biotinylayed probes in cryostat and paraffin sections. Histochem $\mathcal{F} 1987 ; 19: 488-96$.

12 Van Dekken $H$, Kerstens HMJ, Tersteeg TA, Verhofstad AAJ, Vooijs GP. Histological preservation after in situ AAJ, Vooijs GP. Histological preservation after in situ hybridisation to archival solid tumour sections allows
discrimination of cells bearing numerical chromosome discrimination of cells bearing nu
changes. $\mathcal{F}$ Pathol 1992;168:317-24.

13 Waye JS, Willard HF. Chromosome specificity of satellite DNAs: short and long-range organisation of a diverged dimeric subset of human alpha satellite from chromosome 3. Chromosoma 1989;97:475-80.

14 Baldini A, Rocchi M, Archidiacono N, Miller OJ, Miller DA. A human alpha satellite DNA subset specific for chromosome 12. Am ₹ Hum Genet 1990;46:784-8.

15 Feinberg AP, Vogelstein B. A technique for radiolabelling DNA restriction endonuclease fragments to high specific activity. Addendum. Analyt Biochem. 1984;132:166-7.

16 Ankathil R, Vijayakumar T, Pillai GR, Nair MK. Chromosomes in Hodgkin's disease: analysis of involved lymph nodes. Neoplasma 1992;39:245-8.

17 Arnoldus EPJ, Dreef EJ, Noordermeer IA, Verheggen MM, Thierry RF, Peters ACB, et al. Feasibility of in situ hybridization with chromosome specific probes on paraffin wax embedded tissue. 7 Clin Pathol 1991;44:900-4.

18 Beck JLM, Hopman AHN, Feitz WFJ, Schalken J, Schaafsma HE, Van De Kaa CA, et al. Numerical Schaafsma HE, Van De Kaa CA, et al. Numerical
aberrations of chromosomes 1 and 7 in renal cell carcinomas as detected by interphase cytogenetics. 7 Pathol carcinomas as detect

19 Weber-Matthiesen K, Deerberg J, Poetsch M, Grote W, Sclegelberger B. Numerical chromosome aberrations are present within the CD30+ Hodgkin and Reed-Sternberg cells in $100 \%$ of analysed cases of Hodgkin's disease. Blood 1995;86:1464-8.

20 Inghirami G, Macri L, Rosati S, Ying Zhu B, Yee HT, Knowles DM. The Reed-Sternberg cells of Hodgkin disease are clonal. Proc Natl Acad Sci USA 1994;91:9842-6.

21 Weiss LM, Strickler JG, Warnke RA, Sklar J. Immunoglobulin gene rearrangements in Hodgkin's diseases. Hum Pathol 1986;17:1009-14.

22 Delabie J, Tierens A, Weisenburger DD, Chan WC. Nodular sclerosis Hodgkins disease-lineage and clonality analysis using a single cell assay. FASEB $\mathcal{F}$ 1995;9:272A.

23 Weiss LM, Movahed LA, Warnke RA, Skalr J. Detection of Epstein-Barr viral genomes in Reed-Sternberg cells of Hodgkin's disease. N Engl f Med 1989;320:502-6.

24 Stein $\mathrm{H}$, Hummel M, Ziemann K, Lammert H. Hodgkin's disease-its nature and clonality [abstract]. Exp Hematol 1995;8:895.

25 Chan WC, Delabie J. Hodgkin's disease-lineage and clonality. Am f Clin Pathol 1995;4:368-370. 